\title{
GMR
}

\section{Cloning and expression of the 4D8 gene from Hyalomma asiaticum tick}

\author{
Z.Q. Liu ${ }^{1,2 *}$, J. Xia ${ }^{2 *}$, G.L. Wang ${ }^{2}$ and N. Kuermanali ${ }^{2}$ \\ ${ }^{1}$ College of Animal Science, Shihezi University, Shihezi, China \\ ${ }^{2}$ Institute of Veterinary Medicine, Xinjiang Academy of Animal Science, \\ Urumqi, Xinjiang, China \\ *These authors contributed equally to this study. \\ Corresponding author: G.L. Wang \\ E-mail: wangglgl@126.com
}

Genet. Mol. Res. 15 (2): gmr.15027951

Received October 29, 2015

Accepted January 18, 2016

Published June 17, 2016

DOI http://dx.doi.org/10.4238/gmr.15027951

\begin{abstract}
Hyalomma asiaticum tick, an important ectozoic parasite causes tickle, pain, anemia, weight loss, and paralysis in its hosts, which include humans, cattle, sheep, horses, camels, and hares. The 4D8 gene can be a potential vaccine candidate antigen for $H$. asiaticum. In the present study, we cloned and expressed the 4D8 gene of $H$. asiaticum from Xinjiang Province. Primers were designed according to the $H$. asiaticum tick 4D8 gene sequence available in GenBank. The gene was amplified by reverse transcription-polymerase chain reaction and the fragments were subcloned into the prokaryotic expression vector $\mathrm{pET} 30 \mathrm{a}$ and the recombinant vector pET30a-4D8 was constructed. The expressed recombinant protein was purified and its biological activity was investigated by western blot. Results revealed that the recombinant protein was a biologically active fusion protein with a molecular weight of $20 \mathrm{kDa}$. The purified 4D8 protein would provide a strong foundation for further studies on this protein.
\end{abstract}

Key words: Hyalomma asiaticum; 4D8; Clone 


\section{INTRODUCTION}

Hyalomma asiaticum tick is widespread across Xinjiang, Inner Mongolia, Ningxia of China, and central Asia. It mainly affects humans, cattle, sheep, horses, camels, and hares, causing tickle, pain, anemia, weight loss, and paralysis in hosts. Furthermore, it is proved to be the disease vector and reservoir host of Xingjiang hemorrhagic fever and Q fever, playing significant role in public health (Wu et al., 2013). In the 1990s, Bm86 gene expression products were successfully used in developing the commercialized genetic engineering vaccines against Boophilus microplus, named TickGARD and Gavac. These vaccines provided effective tick control in Australia, Cuba, Brazil, and other countries (Rodríguez et al., 1995; Willadsen et al., 1995). However, immunology studies on $H$. asiaticum ticks are few. Recently, 4D8 gene was discovered in several species of ticks (de la Fuente et al., 2006a). RNA interference experiments confirmed that the 4D8 gene silencing seriously affects reproduction and development of ticks (de la Fuente et al., 2005), indicating that 4D8 gene could be an important vaccine candidate antigen. However, no studies on 4D8 gene of $H$. asiaticum ticks have been reported from China. In the present study, we focused on the cloning and expression of the 4D8 gene of $H$. asiaticum tick from Xinjiang province and investigated the immunological characteristics of its expression product. Our results provide sufficient basis for further studies on the biological function of $H$. asiaticum tick.

\section{MATERIAL AND METHODS}

\section{Main reagents and enzymes}

Ex Taq DNA polymerase, restriction enzyme EcoRI, T4 DNA ligase, DNA gel extraction kit, rapid plasmid extraction kit, DNA Marker DL 2000, and DNA Marker DL 15000 were procured from Takara Bio Inc. (Dalian, China). One Step RT-PCR Kit was purchased from Promega (Wisconsin, USA), and X-gal, IPTG, isopropanol, peptone, and other conventional reagents were procured from local vendors in China or were imported. Trizol was purchased from Invitrogen (California, USA), and pMD18-T vectors and E. coli JM109 cells were purchased from Takara Bio Inc. Expression vector pET30a and E. coli BL21 cells were purchased from Amersham (Sweden). Yeast extract and tryptone were purchased from Sangon Biotech (Shanghai) Co., Ltd.

\section{Design and synthesis of primers}

Primers were designed based on the H. asiaticum tick 4D8 gene sequence, obtained from GenBank. NdeI and XhoI restriction sites were introduced into the 5 '-end of the upstream and downstream primers (the underlined part). Sequences of the two primers were: Upstream primer: 5'-GCACATATGATGGCTTGTGCGACATTAAA-3'; Downstream primer: 5'-CGCCTCGAGTTACGACAAATAGCTGGGCGTA-3'. Primers were synthesized by Sangon Biotech Co. Ltd. (Shanghai, China).

\section{Cloning and identification of the target gene}

\section{RNA extraction}

An individual $H$. asiaticum tick was selected, rinsed with phosphate buffer saline 
(PBS), and ground in liquid nitrogen with a mortar and pestle. One milliliter Trizol was added to it, and the homogenate was transferred to a $1.5 \mathrm{~mL}$ Epoxy epoxide (EP) tube. Total RNA was extracted using Trizol according to the manufacturer instructions.

Reverse transcription-polymerase chain reaction (RT-PCR) was performed using the Access one-step RT-PCR system as per the manufacturer instructions. Briefly, RT-PCR mixture was prepared in a $50-\mu \mathrm{L}$ PCR tube, and the following reagents were sequentially added using the pipette tips treated with 0.1 diethyl pyrocarbonate (DEPC) water: AMV/TfI $10 \mu \mathrm{L} 5 \mathrm{X}$ buffer, $1 \mu \mathrm{L}$ dNTP mix, upstream and downstream primers $1 \mu \mathrm{L}$ each, $2 \mu \mathrm{L} 25 \mathrm{mM} \mathrm{MgSO}_{4}, 1 \mu \mathrm{L}$ AMV Reverse Transcriptase $(5 \mathrm{~g} / \mu \mathrm{L}), 1 \mu \mathrm{L}$ TfI DNA Polymerase $(5 \mathrm{~g} / \mu \mathrm{L}), 2 \mu \mathrm{L}$ RNA template, and $31 \mu \mathrm{L}$ nuclease-free water. The above reagents were mixed well. RT-PCR cycle conditions used were: $45^{\circ} \mathrm{C}$ for $45 \mathrm{~min}, 94^{\circ} \mathrm{C}$ for $2 \mathrm{~min} ; 40$ cycles of $94^{\circ} \mathrm{C}$ for $30 \mathrm{~s}, 55^{\circ} \mathrm{C}$ for $1 \mathrm{~min}, 72^{\circ} \mathrm{C}$ for 2 min; $72^{\circ} \mathrm{C}$ for $10 \mathrm{~min}$, and a final hold at $4^{\circ} \mathrm{C}$. Electrophoretic separation was performed using 8 $\mu \mathrm{L}$ RT-PCR products on a $1 \%$ agarose gel. Positive RT-PCR products were gel-purified.

\section{Cloning and identification}

The products recovered from the gel and the expression vector pET30a were digested with $N d e I$ and $X h o I$ and the digested fragments were recovered. The enzymatic reaction mixture used was: $5 \mu \mathrm{L}$ recovered products and expression vector pET30a, $3 \mu \mathrm{L} 10 \mathrm{X}$ buffer, $3 \mu \mathrm{L} 1.0 \mathrm{~mL} / \mathrm{L}$ BSA, $3 \mu \mathrm{L} 1.0 \mathrm{~g} / \mathrm{L}$ Triton X-100, $2 \mu \mathrm{L} N d e \mathrm{I}, 2 \mu \mathrm{L}$ XhoI, and the total volume was made up to $30 \mu \mathrm{L}$ with sterile water. Digested vector fragment $(2 \mu \mathrm{L})$ and the digested recovery product fragments $(6 \mu \mathrm{L})$ were mixed and then $1 \mu \mathrm{L} 10 \mathrm{X}$ ligation buffer and 0.5 $\mu \mathrm{L}$ T4 DNA ligase $(350 \mathrm{IU} / \mathrm{mL})$ was added to them. The total volume was made up to $10 \mu \mathrm{L}$ with sterile water; it was mixed properly and then kept for ligation at $16^{\circ} \mathrm{C}$, overnight. BL21 competent cells were used for transfection. Single colonies were picked and the plasmid was extracted. PCR, enzyme digestion, and sequencing were performed for identification of the positive clones; the recombinant expression plasmid was named pET30a-4D8.

\section{Induction of expression and purification of recombinant plasmid}

\section{Induced expression}

LB medium $(2.5 \mathrm{~mL})$ supplemented with $30 \mathrm{mg} / \mathrm{mL}$ kanamycin, was inoculated with positive clones at a ratio of $1: 100$, and the cells were cultured at $37^{\circ} \mathrm{C}$ with shaking at $220 \mathrm{rpm}$, for about $3 \mathrm{~h}$. When the OD value reached approximately $0.6,0.5 \mathrm{mM}$ IPTG was added to induce the expression at $37^{\circ} \mathrm{C}$ with shaking at $220 \mathrm{rpm}$ for $4 \mathrm{~h}$. The uninduced cultures were used as negative controls. Bacteria were harvested at $2500 \mathrm{~g}$ for $10 \mathrm{~min}$ and the supernatant was discarded. Pellet containing the bacteria were suspended in $500 \mu \mathrm{L} \mathrm{PBS,} \mathrm{pH} \mathrm{7.4,} \mathrm{and} \mathrm{ultrasonication} \mathrm{was} \mathrm{carried}$ out for $6 \mathrm{~min}$, with on and off process cycle of 0.5 and $1.5 \mathrm{~s}$, respectively. After centrifugation, the precipitate and supernatant were collected, and the precipitate was dissolved in $500 \mu \mathrm{L}$ inclusion body lysate (8M Urea, $50 \mathrm{mM}$ Tris-HCl, and $150 \mathrm{mM} \mathrm{NaCl}, \mathrm{pH} 8.0$ ). Each sample (40 $\mu \mathrm{L}$ ) was mixed with $10 \mu \mathrm{L} 5 \mathrm{X}$ protein loading buffer and incubated in boiling water for $10 \mathrm{~min}$.

\section{Nickel-agarose affinity chromatography}

$\mathrm{Ni}$-(iminodiacetic acid) IDA $(5 \mathrm{~mL})$ was washed clean with 10 times bed volume of bind- 
ing buffer at a flow rate $5 \mathrm{~mL} / \mathrm{min}$. Solution was added on the column and the flow rate was adjusted to $2 \mathrm{~mL} / \mathrm{min}$. The flow through was collected. Binding buffer (10 times bed volume) at a flow rate of $5 \mathrm{~mL} / \mathrm{min}$ was used for cleaning the column. Impurities were eliminated with wash buffer at a flow rate $2 \mathrm{~mL} / \mathrm{min}$ and the eluent was collected. Elution buffer was applied at a flow rate 2 $\mathrm{mL} / \mathrm{min}$ and the eluent was collected. The collected samples were analyzed with SDS-PAGE and those showing the highest purity were dialyzed with PBS, 0.1\% SKL, pH 7.4. The dialyzed products were filtered with $0.45 \mathrm{~mm}$ filter membrane, concentrated, subpackaged, and stored at $-80^{\circ} \mathrm{C}$.

\section{SDS-PAGE and western blot analysis of expression products}

\section{SDS-PAGE}

The collected samples were analyzed by electrophoresis on a $12 \%$ SDS-polyacrylamide gel in Tris-Glycine electrophoresis buffer. Ten microliter samples were loaded and the electrophoresis through the stacking gel was performed under $80 \mathrm{~V}$ for $20 \mathrm{~min}$ and when the samples reached the separating gel electrophoresis was continued at $120 \mathrm{~V}$ for $60 \mathrm{~min}$. Coomassie brilliant blue staining of the gel was carried out after the electrophoresis for $20 \mathrm{~min}$, followed by destaining.

\section{Western blot analysis}

Polyacrylamide gel consisting of 5\% stacking and $8 \%$ separating gel was prepared. Purified protein $(5 \mu \mathrm{g})$ was loaded on the gel and electrophoresis was conducted under $80 \mathrm{~V}$ in stacking gel for $30 \mathrm{~min}$ and $120 \mathrm{~V}$ in separating gel for $60 \mathrm{~min}$. Transfer on the membrane was performed under wet condition, at $250 \mathrm{~mA}$ for 90 min. Blocking was done with $5 \%$ skimmed milk powder, with slow shaking at $37^{\circ} \mathrm{C}$ for $2 \mathrm{~h}$. The primary antibody was rabbit anti-His Tag antibody, which was used at a dilution of 1:500. Incubation was done with slow shaking at $37^{\circ} \mathrm{C}$ for $60 \mathrm{~min}$. The secondary antibody was goat anti-rabbit antibody, which was used at a dilution of 1:8000. Incubation was done with slow shaking at $37^{\circ} \mathrm{C}$ for $60 \mathrm{~min}$ and was followed by chromogenic detection using tetramethylbenzidine (TMB).

\section{RESULTS}

\section{Amplification of the 4D8 gene}

RT-PCR amplification resulted in gene fragments of about $500 \mathrm{bp}$, which were as per the expected size (Figure 1).

\section{SDS-PAGE analysis of 4D8 gene expression products}

Results of SDS-PAGE confirmed that the target protein of about $20 \mathrm{kDa}$ was expressed (Figure 2).

\section{D8 protein purification by Nickel-agarose affinity chromatography}

Target protein was obtained in eluent buffer containing different concentrations of imidazole (Figure 3). 


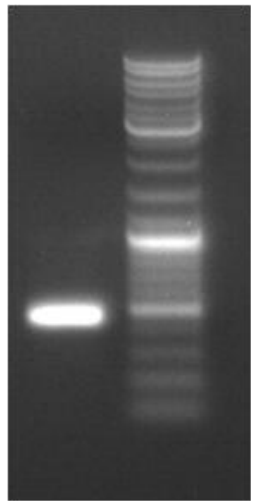

Figure 1. 4D8 gene amplification of Hyalomma asiaticum tick from Xinjiang Province.

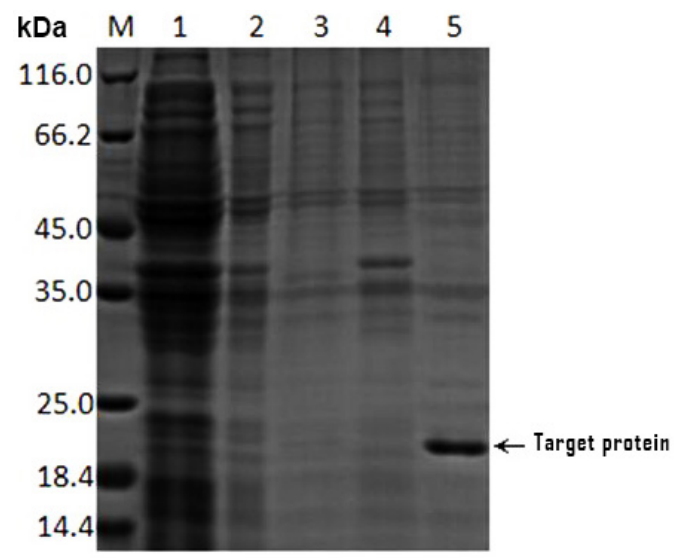

Figure 2. SDS-PAGE results of the fusion protein. Lane $M=$ protein marker; lane $1=$ total protein before induction; lane $2=20^{\circ} \mathrm{C}$ supernatant; lane $3=20^{\circ} \mathrm{C}$ precipitate; lane $4=37^{\circ} \mathrm{C}$ supernatant; lane $5=37^{\circ} \mathrm{C}$ precipitate.

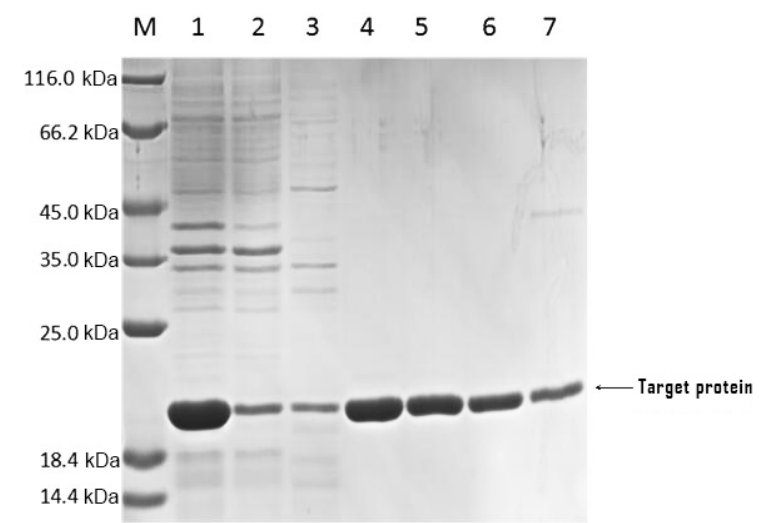

Figure 3. SDS-PAGE of 4D8 protein purified by Nickel-agarose affinity chromatography. Lane $1=$ loading sample; lane 2 = outflow; lane $M=$ protein marker; lane $3=20 \mathrm{mM}$ imidazole elution fractions; lanes $4-6=50 \mathrm{mM}$ imidazole elution fractions; lane $7=500 \mathrm{mM}$ imidazole elution fractions. 


\section{Western blot}

The expression products were analyzed by SDS-PAGE and transferred to nitrocellulose (NC) membrane for western blotting. Results demonstrated that the expression product reacted with the immune serum raised against antigen, which also contained the HIS tag, indicating that the fusion protein was antigenic (Figure 4).

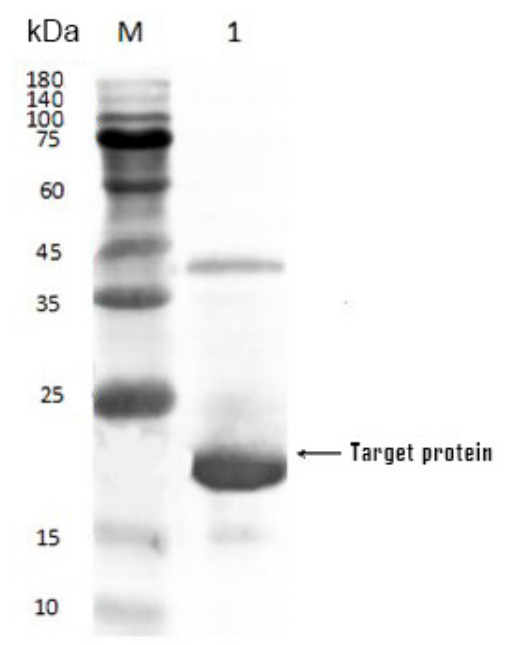

Figure 4. Western blot of 4D8 protein. Lane $M=$ protein marker; lane $1=$ target protein.

\section{DISCUSSION}

$H$. asiaticum tick is an important ectozoic parasite that significantly restricts the development of animal husbandry and threatens human health. Nowadays, prevention of livestock ticks depends mostly on pesticides, residues of which cause food safety, environmental, and other problems, leading to increased public attention. Thus, researchers are gradually shifting from drug prevention to the area of immunological treatment, such as vaccine prevention. The 4D8 gene, which is an antigenic gene with a great protecting function, was discovered in many species of ticks. This gene is a likely candidate for vaccine development against ticks, especially against those species belonging to the same genus. RNA interference studies have shown that the lack of the 4D8 gene led to reduced spawning ability and stunted growth in ticks, similar to the immune effects of Bm86 gene of B. microplus (Kocan et al., 2007; Nijhof et al., 2007). Silencing of Rs86 gene, the homolog of Bm86 gene, and 4D8 gene by RNA interference, significantly reduced the attachment, hemophagia, and spawning ability of Rhipicephalus tick, as well as the hatching ability of its eggs (de la Fuente et al., 2006b), providing a new method for tick vaccine development.

In the present study, we successfully amplified the 4D8 gene of $H$. asiaticum tick from Xinjiang province and cloned it in a prokaryotic expression vector, pET30a. The 4D8 protein was expressed and purified by Nickel-agarose affinity chromatography. The SDS-PAGE showed that the purified protein was about $20 \mathrm{kDa}$, different from the predicted weight of about $19 \mathrm{kDa}$. This might have been because of the fusion of HIS tag to the target protein, leading to its larger molecular weight. Western blot confirmed that the recombinantly expressed product 
had a good reactivity with the specific antibody and was likely to be a candidate protein for vaccine development, although this would require further investigations.

\section{Conflicts of interest}

The authors declare no conflict of interest.

\section{ACKNOWLEDGMENTS}

We thank the anonymous reviewers for reviewing this manuscript.

\section{REFERENCES}

de la Fuente J, Almazán C, Blouin EF, Naranjo V, et al. (2005). RNA interference screening in ticks for identification of protective antigens. Parasitol. Res. 96: 137-141. http://dx.doi.org/10.1007/s00436-005-1351-5

de la Fuente J, Almazán C, Blas-Machado U, Naranjo V, et al. (2006a). The tick protective antigen, 4D8, is a conserved protein involved in modulation of tick blood ingestion and reproduction. Vaccine 24: 4082-4095. http://dx.doi. org/10.1016/j.vaccine.2006.02.046

de la Fuente J, Almazán C, Naranjo V, Blouin EF, et al. (2006b). Synergistic effect of silencing the expression of tick protective antigens 4D8 and Rs86 in Rhipicephalus sanguineus by RNA interference. Parasitol. Res. 99: 108-113. http://dx.doi.org/10.1007/s00436-006-0132-0

Kocan KM, Manzano-Roman R and de la Fuente J (2007). Transovarial silencing of the subolesin gene in three-host ixodid tick species after injection of replete females with subolesin dsRNA. Parasitol. Res. 100: 1411-1415. http:// dx.doi.org/10.1007/s00436-007-0483-1

Nijhof AM, Taoufik A, de la Fuente J, Kocan KM, et al. (2007). Gene silencing of the tick protective antigens, Bm86, Bm91 and subolesin, in the one-host tick Boophilus microplus by RNA interference. Int. J. Parasitol. 37: 653-662. http://dx.doi.org/10.1016/j.ijpara.2006.11.005

Rodríguez M, Penichet ML, Mouris AE, Labarta V, et al. (1995). Control of Boophilus microplus populations in grazing cattle vaccinated with a recombinant Bm86 antigen preparation. Vet. Parasitol. 57: 339-349. http://dx.doi. org $/ 10.1016 / 0304-4017(94) 00678-6$

Willadsen P, Bird P, Cobon GS and Hungerford J (1995). Commercialisation of a recombinant vaccine against Boophilus microplus. Parasitology 110 (Suppl): S43-S50. http://dx.doi.org/10.1017/S0031182000001487

Wu XB, Na RH, Wei SS, Zhu JS, et al. (2013). Distribution of tick-borne diseases in China. Parasit. Vectors 6: 119. http:// dx.doi.org/10.1186/1756-3305-6-119 